Original Research Paper

\title{
Remediation of Feedlot Nutrients Runoff by Electrocoagulation Process
}

\author{
Arjun Thapa, Shafiqur Rahman and Md. Saidul Borhan \\ Agricultural and Biosystems Engineering, North Dakota State University, Fargo, North Dakota, USA
}

Article history

Received: 13-01-2015

Revised: 09-06-2015

Accepted: 03-11-2015

Corresponding Author:

Shafiqur Rahman

Agricultural and Biosystems

Engineering, North Dakota State

University, Fargo, North Dakota, USA

Tel: 701-231-8351

Fax: 701-231-1008

E-mail: s.rahman@ndsu.edu

\begin{abstract}
Nutrient runoff from Concentrated Animal Feeding Operations (CAFOs) may cause ground and surface water pollution. Scientists and researchers are continually searching for appropriate technologies to mitigate feedlot nutrient runoff pollution. In this study, suitability of electrocoagulation treatment process was examined under laboratory conditions to mitigate nutrient pollutants from the feedlot runoff. Feedlot runoff was treated with three different type of electrodes such as aluminum (Al-Al), iron $(\mathrm{Fe}-\mathrm{Fe})$ and hybrid $(\mathrm{Al}-\mathrm{Fe})$ at different electrical voltage potentials (5, 10 and 15 Volts) for a designated time step (up to $30 \mathrm{~min}$ ). The electrocoagulation cell consisted of two parallel rectangular plate electrodes, immersed in a beaker with $500 \mathrm{~mL}$ feedlot runoff and powered by a Direct Current (DC) supply. This study was conducted in batches at room temperature. Results indicated that Electrical Conductivity (EC), Total Phosphorus (TP), Total Nitrogen (TN) and Chemical Oxygen Demand (COD) concentration reduced significantly irrespective of electrode types. Overall, TP concentration reduction was higher $(100 \%)$ followed by COD (50-75\%) and TN (25-60\%) concentration. Nutrient removal and specific electrical energy consumption increased with increasing voltage level. Aluminum electrodes were more effective than the other two electrodes for TP reduction at all applied potentials and COD reduction was better at lower applied potential. Hybrid electrodes (Al-Fe) reduced $\mathrm{TN}$ better than the other two electrodes.
\end{abstract}

Keywords: Feedlot Runoff, Nutrients, Electrocoagulation, Electrode Potential and Specific Electrical Energy Consumption

\section{Introduction}

Feedlot is a concentrated animal feeding operation where beef cattle are finished to slaughter weight and have little or no access to pasture land (Spellman and Whiting, 2010). Feedlot is a potential source of nutrient runoff, if manure is not managed properly. The runoff generated from the feedlot pen surfaces has a considerable amount of nutrients such as nitrogen, phosphorus, potassium along with organic matter, pathogen, hormone and antibiotics (Crane et al., 1983; Dillaha et al., 1989). This runoff may contaminate surface and groundwater, can cause eutrophication and reduce the oxygen level in surface water which may suppress the biodiversity of lagoons and estuaries (Ansari et al., 2011; Hribar and Schultz, 2010; Prophet and Edwards, 1973). To mitigate this problem, researchers are trying to adopt different technologies such as membrane filtration, advanced oxidation process, air flotation, distillation, evapotranspiration, nitrification, precipitation, ammonia stripping and electro-dialysis (Bensadok et al., 2011; Ilhan et al., 2008). Though some of these methods are effective, sometimes these methods may become complex, expensive and sophisticated which may require specialized technical knowledge (Crites et al., 2014). Moreover, some of the methods may not be economically viable for livestock growers (Kim et al., 2013). Therefore, electrocoagulation can be used for treatment of feedlot runoff to cope with this issue.

Electrocoagulation technology is a treatment process where electrical current is applied to treat and flocculate contaminants (Butler et al., 2011; Mollah et al., 2001). The electrocoagulation process works on the principle of oxidative or reductive chemistry and it needs relatively simple equipment called electrodes at ambient temperature and pressure. Electrocoagulation is 
generated in-situ by electrolytic oxidation of an appropriate anode material (Mollah et al., 2001). They also mentioned that in the coagulation process, charged ionic are removed from wastewater by allowing it to react (i) with an ion having opposite charge, or (ii) with floc of metallic hydroxides generated within the effluent. Electrocoagulation is environmentally compatible, low area demanded, small volume of sludge produced and short treatment time required (Chaturvedi, 2013; Inan and Alaydin, 2014). However, electrocoagulation process also possesses some challenges such as an expensive process due to current uses, an impermeable oxide film may be formed on the cathode and high conductivity of the wastewater suspension is required (Mollah et al., 2001). Typically, runoff water has high conductivity, which overcome of these issues and the sludge produced during electrocoagulation can be used as a fertilizer or used for extracting different valuable elements (Bridle and Skrypski-Mantele, 2000; Gaber et al., 2011; Sano et al., 2012; Sethu et al., 2008). The effluent produced from the electrocoagulation can be used for irrigation. In the past, limited studies on the use of electrocoagulation were performed on livestock wastewater including swine (Bejan et al., 2007; Cho et al., 2010; Laridi et al., 2005; Rahman and Borhan, 2014), dairy (Bensadok et al., 2011; Şengil, 2006; Tchamango et al., 2010; Yavuz et al., 2011), slaughter house wastewater (Bazrafshan et al., 2012), industrial effluents (Ali and Yaakob, 2012; Basha et al., 2008), pharmaceutical wastewater (Yi-zhong et al., 2002), agroindustry (Kim et al., 2013) and textile dye wastewater (Merzouk et al., 2009). However, until today, electrocoagulation was not use to treat feedlot runoff. Therefore, this article investigated the electrocoagulation treatment of feedlot runoff in a batch under laboratory conditions using different electrodes at varying applied electrical potential level. The specific objectives were to compare TP, COD and TN removal efficiencies and energy consumptions of three metal electrodes (ironiron, aluminum-aluminum and iron aluminum combination) in treating feedlot runoff.

\section{Materials and Methods}

\section{Description of Electrocoagulation Operation Systems}

Parallel plates with identical dimensions of aluminum (Al-Al), iron (Fe-Fe) and hybrid (Al-Fe) electrodes pair were used in electrocoagulation process. Electrical power was applied through the single anode and cathode using a DC power source equipped with digital ammeter and voltmeter (BK precision 1621A DC regulated power supply equipment) and maintained at 5,10 or $15 \mathrm{~V}$ electrical potential (Fig. 1). The submerged portion of an electrode was $90 \times 25 \times 1.5 \mathrm{~mm}(h \times b \times t)$ though its actual dimension was $280 \times 25 \times 1.5 \mathrm{~mm}(h \times b \times t)$. The space between the electrodes was kept constant at $8 \mathrm{~mm}$ and the effective submerged area was $4807.5 \mathrm{~mm}^{2}$. Corresponding currents against applying voltage potentials were measured to determine electrical energy consumption. During electrocoagulation, the polarity of electrodes was altered manually to minimize passivation on electrodes and the runoff water in the beaker was mixed continuously with a $30 \mathrm{~mm}$ magnetic stirrer at 200 to $300 \mathrm{rpm}$. After electrocoagulation, the sludge was collected and filtered using 0.45 micron mixed cellulose ester filter (EZ-Pak membrane Filter, Cat\# EZHAWG474) and dried in an oven at $105^{\circ} \mathrm{C}$ for the elemental analysis. Electrodes were rinsed with diluted hydrochloric acid (5\% v/v) followed by De-Ionized (DI) water rinse to avoid the electrode passivation due to oxidation and contamination of products.

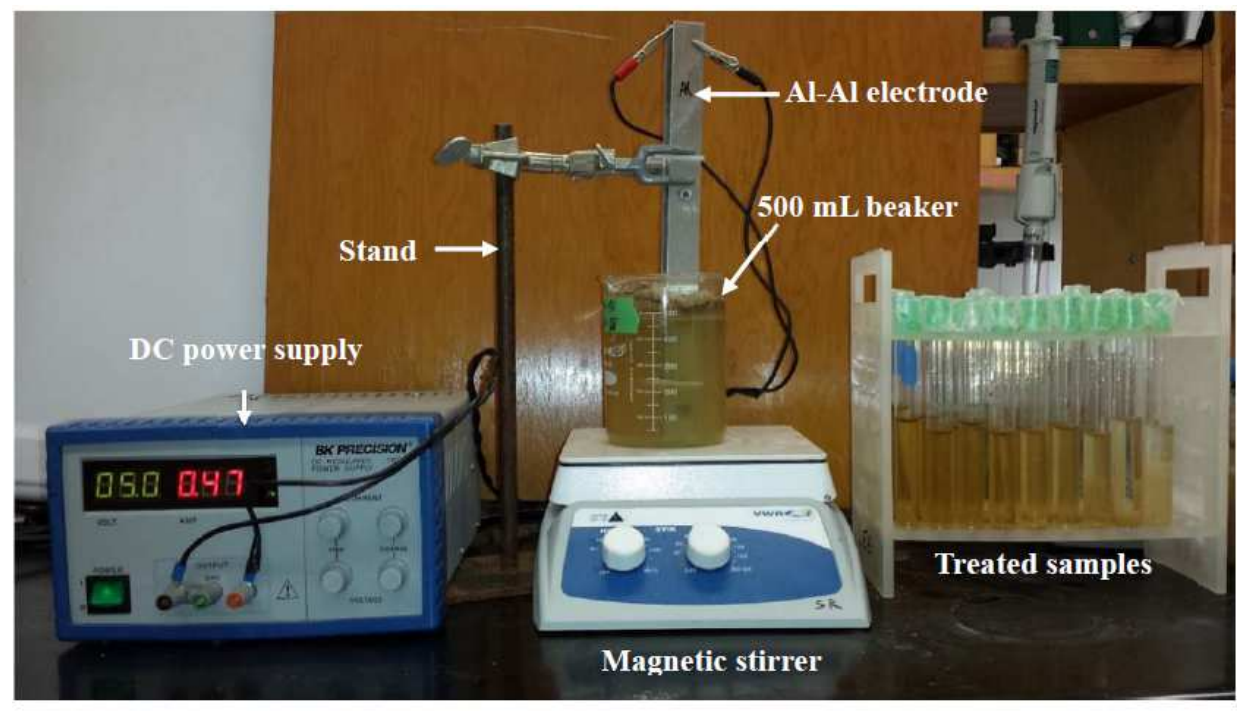

Fig. 1. Photographic views of the electrocoagulation setup used in this study 


\section{Feedlot Runoff Collection, Storage and Sample Collection}

Feedlot runoff samples were collected from the Beef Research Centre at North Dakota State University, Fargo, North Dakota, USA. Collected sample was stored in a $20 \mathrm{~L}$ bucket at $4^{\circ} \mathrm{C}$ and analyzed at room temperature $\left(25 \pm 2^{\circ} \mathrm{C}\right)$. During electrocoagulation, a $500 \mathrm{~mL}$ sample was placed into a $550 \mathrm{~mL}$ beaker. Initial $\mathrm{pH}$ and $\mathrm{EC}$ of runoff wastewater were measured with a handheld $\mathrm{pH}$ and EC meter (YSI Pro Plus, YSI Inc., Ohio, US). Total Solids (TS) contents were measured before starting electrocoagulation treatment. At predetermined times $(0,1,2,3,5,8,10,20$ and 30 min of electrocoagulation) $10 \mathrm{~mL}$ of treated samples were pipetted in test tubes. These samples were left overnight (8-12 h) at room temperature for settlement and nutrient analysis was done later on using treated waste from the supernatant. In this experiment, three potentials such as 5,10 and $15 \mathrm{VDC}$ were applied for each electrode with three replicates. A total of 243 $(3 \times 3 \times 3 \times 9)$ samples were collected during the electrocoagulation study.

\section{Sample and Data Analysis}

Total Solids (TS) contents were measured following the standard procedure (method 2540B, APHA, 2005). The Hach Method 10127 (Molybdovanadate Method with Acid Persulfate Digested, 1-100 $\mathrm{mgL}^{-1}$ ) was used for TP analysis. The Hach Method 10072 (Persulfate digestion method 2-250 $\mathrm{mgL}^{-1}$ ) was used for TN analysis and Hach Method 8000 (Reactor digestion method 20-1500 $\mathrm{mgL}^{-1}$ ) was used for COD analysis. Mineral concentration in the dried sludge was measured with Inductively Coupled Plasma Spectroscopy (ICP) using a 2010-11-15 Standard Method in the Wet Ecosystem Lab at North Dakota State University. The mean concentrations of $\mathrm{pH}$ and $\mathrm{EC}$ were compared before and after an electrocoagulation event. TN, COD and TP concentrations at each time step while treating the runoff were compared with initial concentration. The mean concentration of the pollutants $(\mathrm{EC}, \mathrm{pH}, \mathrm{TP}, \mathrm{COD}$ and $\mathrm{TN}$ ) and estimated removal efficiencies in each voltage potential and electrode type were compared using ANOVA. The null hypothesis tested in the experiment was that there is no significant difference in pollutant concentration across electrode types and applied electrode potentials. All statistical analyses were performed with SAS software (version 9.3) using the PROC means procedure at the $5 \%$ level of significance.

Calculation of Removal Efficiency and Specific Energy Uses

The removal efficiencies for TN, TP and COD were calculated using Equation 1. Similarly, the electrical energy consumption per unit mass of the individual parameters and per unit volume of runoff processed was calculated using the Equations 2 and 3, respectively:

$\%$ Removal efficiency of parameter
$=\frac{\text { Initial concentration }\left(C_{i}\right)-\text { final concentrationi }\left(C_{f}\right)}{\text { Initial concentration }\left(C_{i}\right)}$

Electrical energy consumption $(k W h)$ per unit

mass of parameter $=\frac{V \times I \times t(k W h)}{\text { mass of parameter reduced }(\mathrm{kg})}$

Electrical energy consumption $(k W h)$

per unit volume $=\frac{V \times I \times t(\mathrm{kWh})}{\text { volume of runoff used }\left(\mathrm{m}^{3}\right)}$

Where:

$V=$ Applied potential difference in electrocoagulation process, voltage

$I=$ Current generated in electrocoagulation process, amperes

$t=$ Time of electrocoagulation process, hours

\section{Results and Discussion}

\section{Initial Concentration of Feedlot Runoff Nutrients}

The average initial nutrient concentrations of 27 samples of feedlot runoff used in this study are listed in Table 1. Following electrocoagulation experiment, subsequent changes are reported and discussed in the following sections.

\section{$p H$ and Electrical Conductivity (EC) Change in Feedlot Runoff}

In most of the cases, after electrocoagulation, the $\mathrm{pHs}$ of the electrocoagulation solution were increased except for $10 \mathrm{~V} \mathrm{Al-Fe}$ electrodes and $5 \mathrm{~V} \mathrm{Al}-\mathrm{Al}$ electrodes (Fig. 2 ). The increased $\mathrm{pH}$ in electrocoagulation solution was likely due to the excess hydroxyl ions produced at the cathode and liberation of free OH- (Dalvand et al., 2011; Feng et al., 2007). In this study, following electrocoagulation, the $\mathrm{pHs}$ of the electrocoagulation solution increased except for $10 \mathrm{~V} \mathrm{Al-Fe}$ electrodes and $5 \mathrm{~V}$ Al-Al electrodes. Iron electrodes $(\mathrm{Fe}-\mathrm{Fe})$ treated runoff had the highest $\mathrm{pH}$, whereas $\mathrm{Fe}-\mathrm{Al}$ treated runoff had the lowest $\mathrm{pH}$. Aluminum electrodes (Al-Al) treated runoff resulted $\mathrm{pH}$ in between these two types of electrodes. It is also evident from Fig. 2 that the electrocoagulation had effects on $\mathrm{pH}$ change and almost all cases $\mathrm{pH}$ levels were increased due to electrocoagulation. 


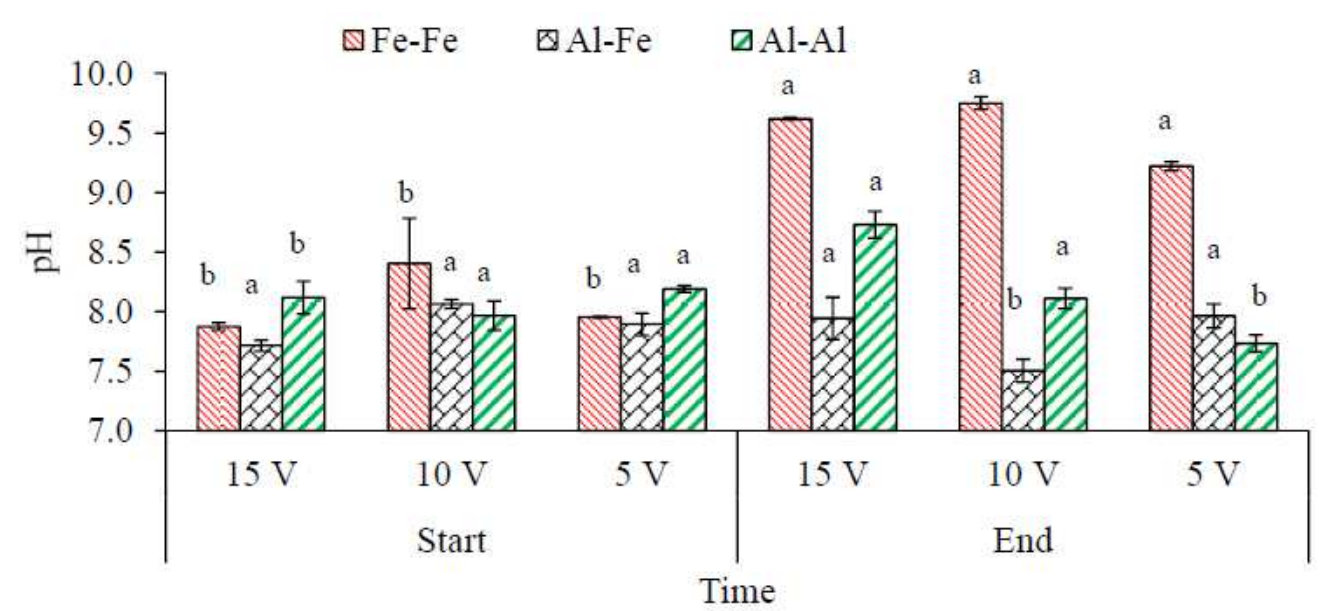

Fig. 2. $\mathrm{pH}$ of the feedlot runoff at start and end of electrocoagulation by different electrodes. The bars with the same letter between start $(0 \mathrm{~min})$ and end time $(30 \mathrm{~min})$ for an electrode at an applied electrode potential are not significantly different at $\mathrm{p} \leq 0.05$

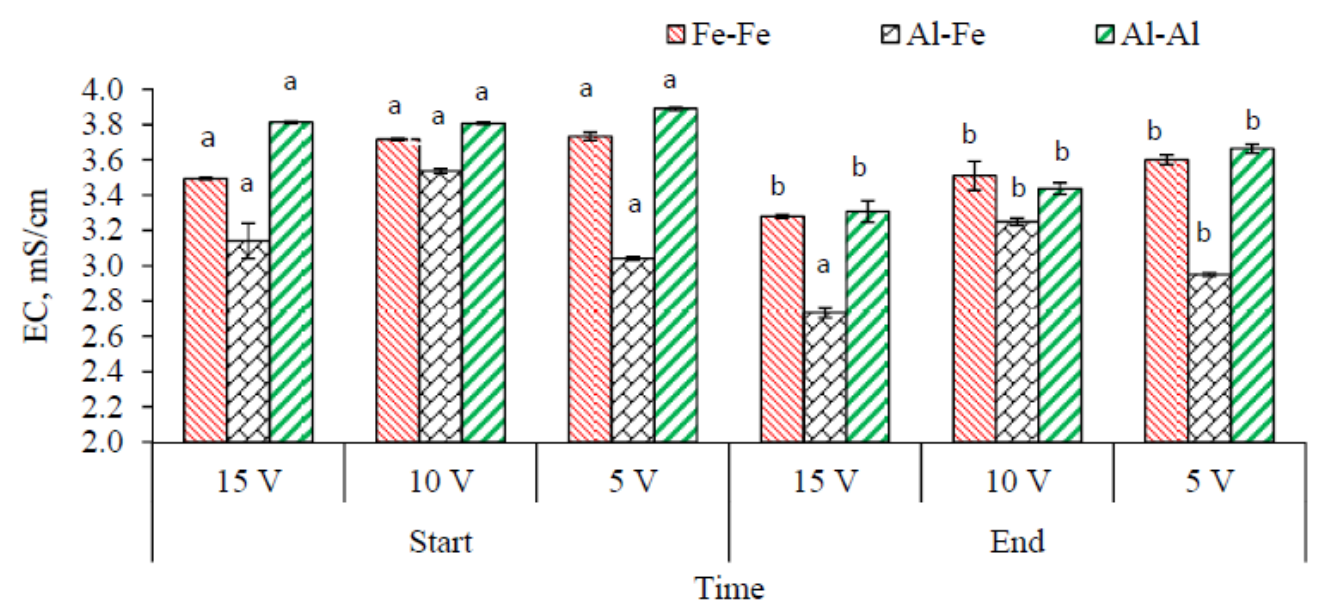

Fig. 3. Effect of electrode types and voltage potentials on Electrical Conductivity (EC) values while electro-coagulating feedlot runoff. The bars with the same letter between start $(0 \mathrm{~min})$ and end time $(30 \mathrm{~min})$ for an electrode at an applied electrode potential are not significantly different at $\mathrm{p} \leq 0.05$

This study demonstrated that the EC of the wastewater samples were decreased significantly following electrocoagulation (Fig. 3). The highest EC reductions were observed at an applied voltage of $15 \mathrm{~V}$ (3.49 to $3.28 \mathrm{mS} \mathrm{cm}^{-1}$ for $\mathrm{Fe}-\mathrm{Fe}, 3.81$ to 3.31 for $\mathrm{Al}-\mathrm{Al}$ electrodes and 3.14 to $2.73 \mathrm{mS} \mathrm{cm} \mathrm{cm}^{-1}$ for $\mathrm{Al}-\mathrm{Fe}$ electrodes), followed by $10 \mathrm{~V}$ (3.72 to 3.51 for Fe-Fe, 3.54 to $3.25 \mathrm{mS} \mathrm{cm}^{-1}$ for $\mathrm{Al}-\mathrm{Fe}, 3.81$ to $3.44 \mathrm{mS} \mathrm{cm}^{-1}$ for $\mathrm{Al}-\mathrm{Al}$ electrodes) and $5 \mathrm{~V}$ (3.73 to $3.60 \mathrm{mS} \mathrm{cm}^{-1}$ for Fe$\mathrm{Fe}, 3.04$ to $2.95 \mathrm{mS} \mathrm{cm}^{-1}$ for $\mathrm{Al}-\mathrm{Fe}$ and 3.89 to $3.66 \mathrm{mS}$ $\mathrm{cm}^{-1}$ for $\mathrm{Al}-\mathrm{Al}$ electrodes).

This study demonstrated that the EC of the wastewater samples was decreased significantly following electrocoagulation. The Al-Fe electrodes at $15 \mathrm{~V}$ resulted in the highest $\mathrm{EC}$ reduction than the $\mathrm{Fe}-$ $\mathrm{Fe}$ and $\mathrm{Al}-\mathrm{Al}$ electrodes during $30 \mathrm{~min}$ of electrocoagulation time. On the contrary, with $10 \mathrm{~V}$ and $5 \mathrm{~V}$ applied electrical potentials and 30 min treatment time; Al-Al electrodes reduced more EC than $\mathrm{Fe}-\mathrm{Fe}$ and $\mathrm{Al}-\mathrm{Fe}$ electrodes. The changes in EC during electrocoagulation were likely to occur by the free ions present in the solution.

In practice, after electrocoagulation, the electrostatic charge of dispersed particles present in the solution are neutralized and thus the EC of the solution is reduced (K1lı̧̧ and Hoşten, 2010). Tchamango et al. (2010) also mention that by means of electrocoagulation process EC could be decreased due to the consumption of protons by transformation of phosphoric acid into solid metal phosphate. This indicates that the unwanted ions were settled down by the formation of insoluble product or neutralized by charged metal ions during electrocoagulation process, 
which helps to purify the wastewater during the wastewater treatment process.

\section{Total Phosphorus (TP) Reduction}

In this experiment, TP reduction was $100 \%$ within $30 \mathrm{~min}$ of treatment time by all electrodes combinations and at all three applied electrical potential levels. At 15, 10 and $5 \mathrm{~V}$ applied voltage potentials, approximately $100 \%$ TP reduction was achieved within 3 to $5 \mathrm{~min}, 3$ to $10 \mathrm{~min}$ and 8 to 10 min, respectively, irrespective of electrode types and combination (Fig. 4a to c). The Al-Al and Fe-Fe electrodes reduced TP concentration significantly within $3 \mathrm{~min}$ of treatment initiation than Al-Fe electrodes for an applied potential of $15 \mathrm{~V}$ (Fig. 4a) and $10 \mathrm{~V}$ (Fig. 4b). However, Al-Fe electrode took 8 min for an applied potential of $5 \mathrm{~V}$ (Fig. 4c).

Overall, Al-Al electrodes had shown better TP removal than other electrodes under test conditions (Fig. 4). According to others (Dinh-Duc et al., 2014; Ilhan et al., 2008; Inan and Alaydin, 2014; Laridi et al., 2005), the TP reductions were mainly due to the production of $\mathrm{Al}$ or $\mathrm{Fe}$ ions in an anode. The $\mathrm{OH}-$ produced in the cathode is immediately react with metal ions in the runoff and produce metallic hydroxides. Subsequently, this process initiates polymerization reactions when metallic hydroxide particles reached a sufficient concentration and react with phosphate ions present in the solution and formed either aluminum or iron phosphate and sedimentated in the solution and helps to reduce total phosphorus from the wastewater (Dinh-Duc et al., 2014; Ilhan et al., 2008; Inan and Alaydin, 2014; Laridi et al., 2005).

\section{Total Nitrogen (TN) Reduction}

Total Nitrogen (TN) concentration at different treatment times during an electrocoagulation process for an applied voltage is presented in Fig. 5a to c. For all electrodes tested in this study, the highest TN reduction occurred at $15 \mathrm{~V}$ electrical potentials (Fig. 7) when compared with $10 \mathrm{~V}$ (Fig. 5b) and $5 \mathrm{~V}$ (Fig. 5c) applied electrode potentials. At $15 \mathrm{~V}$ applied electrical potential and $30 \mathrm{~min}$ treatment time, TN reduction was approximately 63,56 and $41 \%$ for Al$\mathrm{Fe}, \mathrm{Al}-\mathrm{Al}$ and Fe-Fe electrodes, respectively (Fig. 5a). Similarly, at $10 \mathrm{~V}$ potential and $30 \mathrm{~min}$ treatment, the TN reductions were approximately 47,42 and $38 \%$ for $\mathrm{Al}-\mathrm{Al}, \mathrm{Al}-\mathrm{Fe}$ and $\mathrm{Fe}-\mathrm{Fe}$ electrodes, respectively (Fig. $5 \mathrm{~b})$. However, at $5 \mathrm{~V}$ for the same treatment time, FeFe electrodes resulted in the lowest $\mathrm{TN}$ reduction (Fig. $5 \mathrm{c})$. The $\mathrm{TN}$ reduction at $5 \mathrm{~V}$ and $30 \mathrm{~min}$ treatment time by the Al-Al, Al-Fe and Fe-Fe electrodes were about 45,38 and $27 \%$ by, respectively (Fig. 5c).
Similarly, the highest $\mathrm{TN}$ reduction occurred at 15 $\mathrm{V}$ electrical potentials for all electrodes as compared to another electrode potential. At $15 \mathrm{~V}$ applied electrode potential, Al-Fe electrodes reduced significantly greater amount of TN than the Al-Al and Fe-Fe electrodes (Fig. 5a). Similarly, with $10 \mathrm{~V}$ potential, Al-Al electrodes reduced significant amount of TN than the Al-Fe and Fe-Fe electrodes (Fig. 5b). For $5 \mathrm{~V}$ electrode potential, $\mathrm{Al}-\mathrm{Fe}$ and Al-Al electrodes reduced significant amount of TN than the Fe-Fe electro (Fig. 5c). Therefore, any of the electrode combinations may be used in reducing $\mathrm{TN}$, but $\mathrm{Al}-\mathrm{Al}$ and $\mathrm{Al}-\mathrm{Fe}$ electrodes combination performed the best at greater applied potential $(15 \mathrm{~V})$. The main reason for $\mathrm{TN}$ reduction are denitrification, ammonia stripping, hydrogen electroflotation, electron oxidation and electrocoagulation (Kabuk et al., 2014).

\section{Chemical Oxygen Demand (COD) Change}

During the electrocoagulation process, three levels of voltage potentials were applied. Among them, $15 \mathrm{~V}$ applied electrical potential reduced the highest percentage of COD (Fig. 6a) than those $10 \mathrm{~V}$ (Fig. 6b) and $5 \mathrm{~V}$ (Fig. 6c). With higher electrode potential, higher nutrient reductions were likely due to the release of higher amount of metal ions to the runoff wastewater, thus reducing more COD by electrocoagulation. At $15 \mathrm{~V}$ applied potential and at $30 \mathrm{~min}$ of treatment time, the COD reduction was about $78 \%$ by all the electrodes and the differences in COD reduction among the electrodes were not significant (Fig. 6a). Similarly, for the same treatment time, an applied potential of $10 \mathrm{~V}$ reduced COD concentration by approximately 73, 68 and $67 \%$ for $\mathrm{Al}-\mathrm{Al}, \mathrm{Al}-\mathrm{Fe}$ and $\mathrm{Fe}-\mathrm{Fe}$ electrodes, respectively, but no significant differences among electrode types in terms of COD reduction was achieved (Fig. 6b).

The highest COD reduction was also obtained at $15 \mathrm{~V}$ applied electrical potential than those observed at $10 \mathrm{~V}$ and $5 \mathrm{~V}$ electrical potential. The COD reduction was much lower with $5 \mathrm{~V}$ than those of 10 and $15 \mathrm{~V}$ electrical potential. However, at each level of electrical potentials, COD reduction increased with increasing treatment time. Therefore, any of the electrode combinations at $15 \mathrm{~V}$ electrical potential may be used to reduce COD significantly. This research showed that the removal efficiency of COD increased irrespective of electrode types with increasing applied voltage potentials (5, 10 and $15 \mathrm{~V}$ ) and treatment times. Other researchers (Bensadok et al., 2011; Inan et al., 2004; Laridi et al., 2005; Merzouk et al., 2011; Rivera et al., 2009) also reported that at a particular voltage, removal of COD increased with increased process/treatment time. 


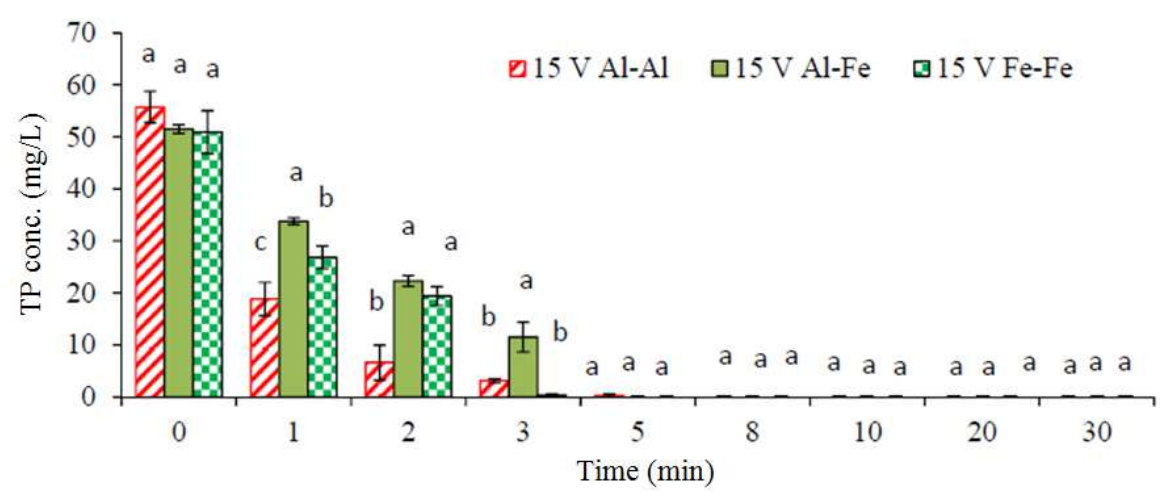

(a)

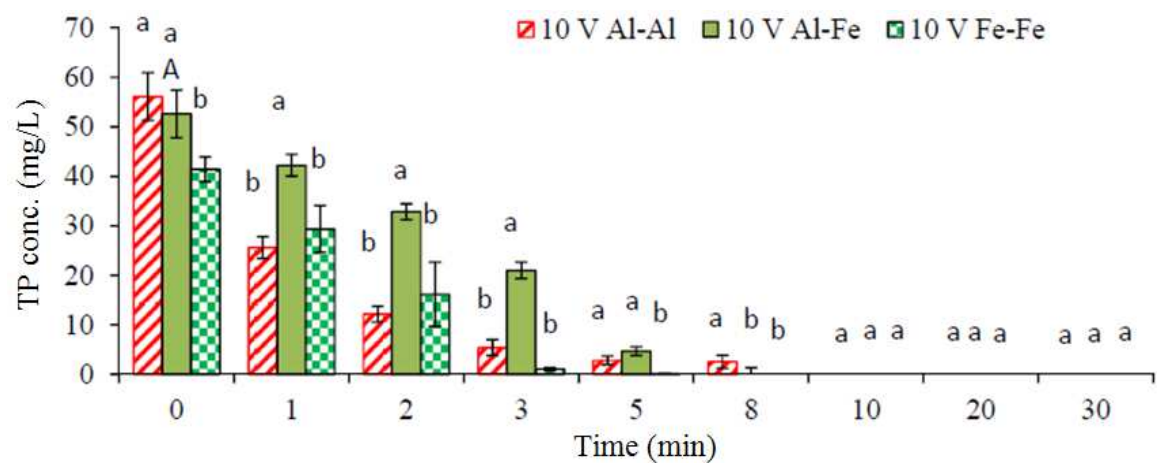

(b)

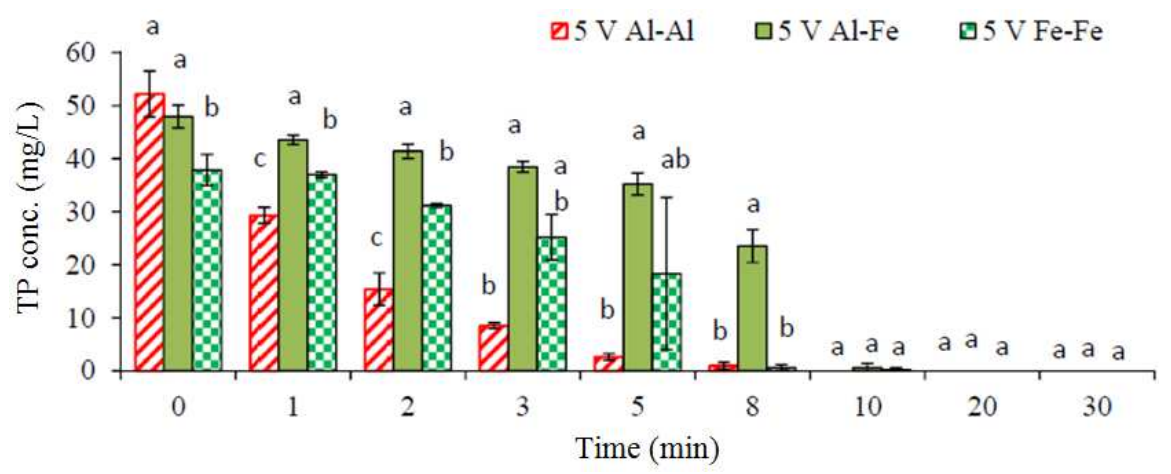

(c)

Fig. 4. Total Phosphorous (TP) values at (a) $15 \mathrm{~V}$ (b) $10 \mathrm{~V}$ and (c) $5 \mathrm{~V}$ applied potential by different electrodes. The bars with the same letter at each sampling time with different electrodes are not significantly different at $\mathrm{p} \leq 0.05$

๑15 V, Al-Al ם15 V, Al-Fe $\square 15 \mathrm{~V}, \mathrm{Fe}-\mathrm{Fe}$

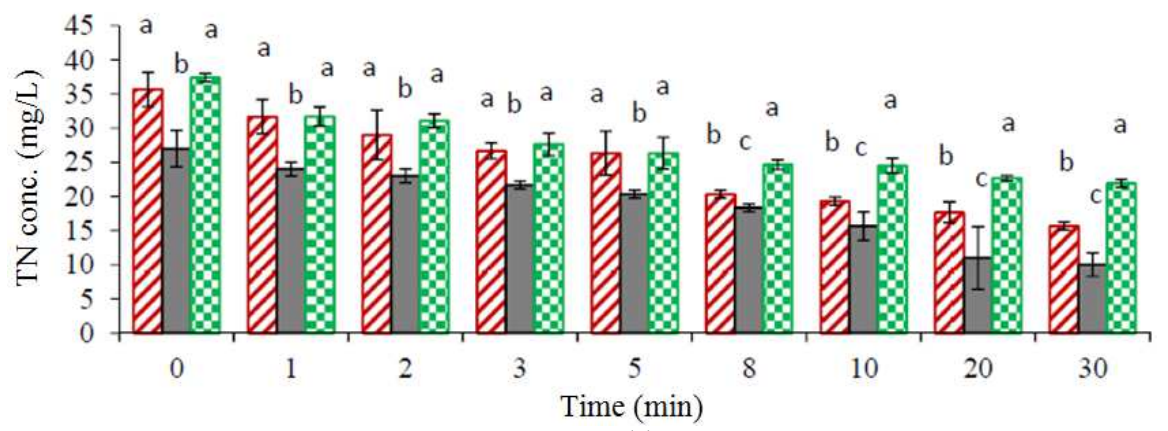

(a) 
$\square 10 \mathrm{~V}, \mathrm{Al}-\mathrm{Al}$ 마. $\mathrm{Al}-\mathrm{Fe} \square 10 \mathrm{~V}, \mathrm{Fe}-\mathrm{Fe}$

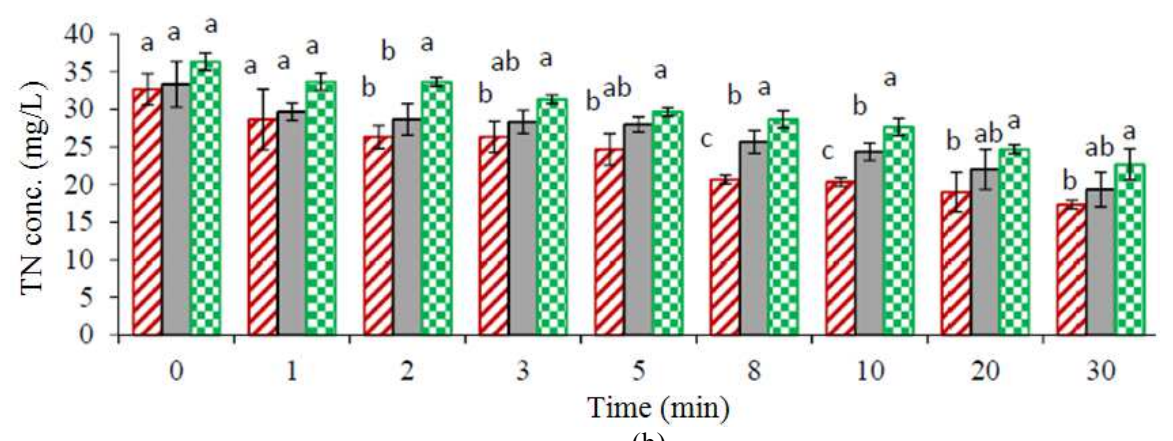

(b)

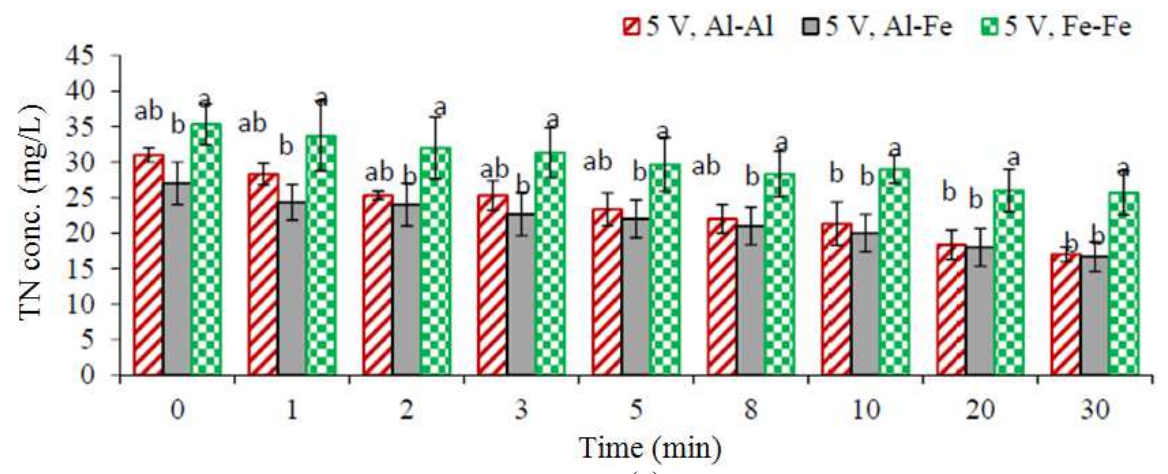

(c)

Fig. 5. Total Nitrogen (TN) values at (a) $15 \mathrm{~V}$, (b) $10 \mathrm{~V}$ and (c) $5 \mathrm{~V}$ applied potential by different electrodes. The bars with the same letter at each sampling time with different electrodes are not significantly different at $\mathrm{p} \leq 0.05$

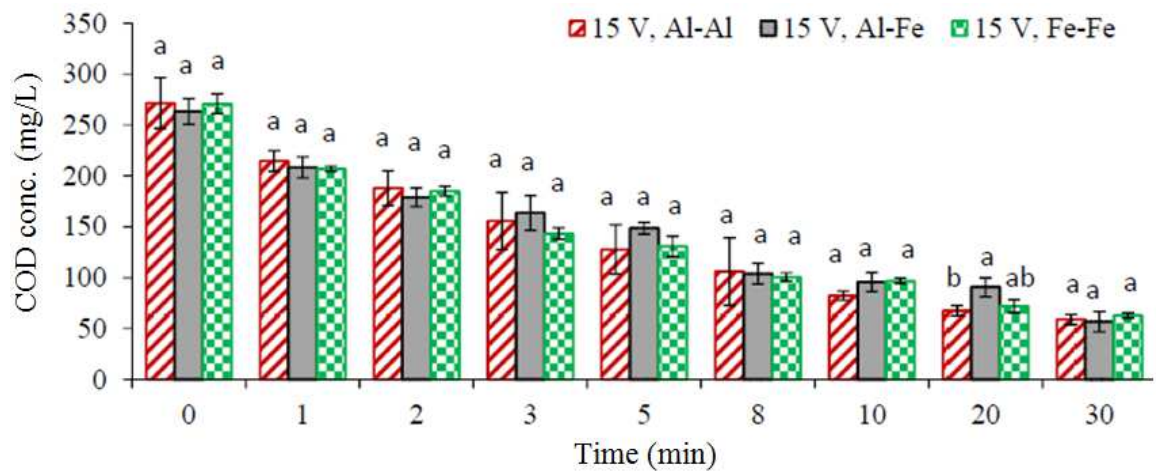

(a)

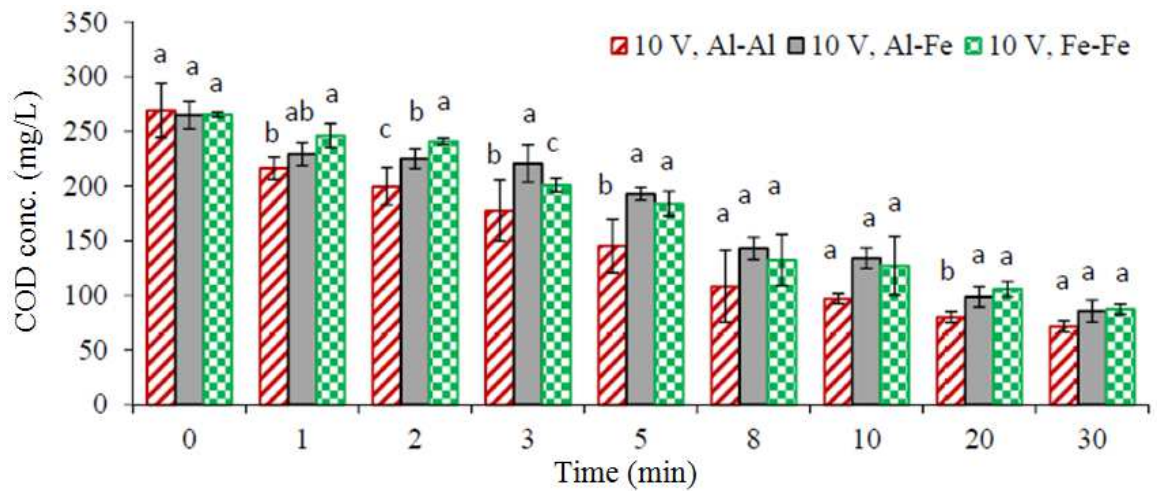

(b) 


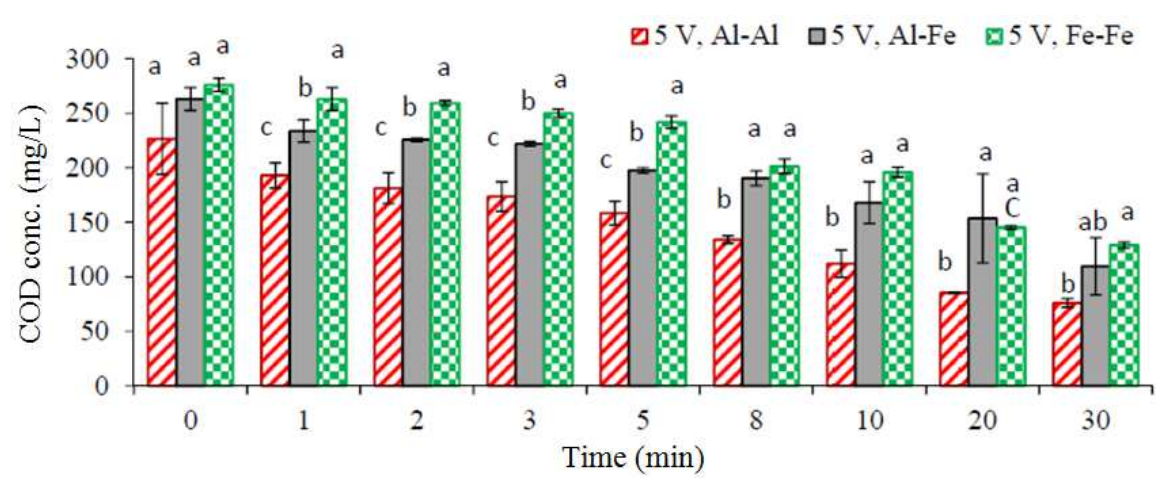

(c)

Fig. 6. Chemical Oxygen Demand (COD) values at (a) 15, (b) $10 \mathrm{~V}$ and (c) $5 \mathrm{~V}$ applied potential by different electrodes. The bars the same letter at each sampling time with different electrodes are not significantly different at $\mathrm{p} \leq 0.05$

Table 1. Initial characteristics of feedlot runoff used in the electrocoagulation experiment

\begin{tabular}{ll}
\hline Parameter & Initial concentration \\
\hline $\mathrm{pH}$ & $8.02 \pm 0.229$ \\
Conductivity $\left(\mathrm{mScm}^{-1}\right)$ & $3.60 \pm 0.30$ \\
$\mathrm{TN}\left(\mathrm{mgL}^{-1}\right)$ & $32.86 \pm 4.17$ \\
$\mathrm{TP}\left(\mathrm{mLL}^{-1}\right)$ & $49.59 \pm 6.52$ \\
$\mathrm{COD}\left(\mathrm{mgL}^{-1}\right)$ & $263.52 \pm 19.50$ \\
$\mathrm{TS}\left(\mathrm{mL}^{-1}\right)$ & $3.06 \pm 0.28$ \\
\hline
\end{tabular}

\section{Specific Electrical Energy Consumption (SEEC)}

For the same treatment time, the SEEC (Energy required per unit $\mathrm{TP}, \mathrm{TN}$ or $\mathrm{COD}$ reduction, or per unit volume of feedlot runoff) was higher for $15 \mathrm{~V}$ applied potential than the 10 and $5 \mathrm{~V}$ applied potential (Table 2). It was also observed that treatment time decreased with increased applied voltage potential for the same amount of TP, COD and TN reduction. Therefore, at higher applied electrical potential, the treatment time of electrocoagulation can be reduced, which is preferable for designing continuous or higher capacity batch reactor for treating feedlot runoff under field condition.

All electrodes removed 100\% TP at similar SEEC, except Al-Al electrodes at 15V. Overall, Fe-Fe electrodes outperformed other electrodes. The lowest SEEC per kg TP removed was estimated 7.98 for Al-AL electrodes. Similarly, the lowest SEEC per kg COD and $\mathrm{TN}$ removed were estimated as 4.77 and 70.89 $\mathrm{kWh}$ /pollutants (Table 2).

\section{Characteristics of Sludge Generated by Different Electrode in Electrocoagulation}

Elemental analysis of sludge generated by the electrocoagulation for $30 \mathrm{~min}$ at $15 \mathrm{~V}$ is presented in Table 3 . The aluminum residue produced by Al-Fe electrodes were $55.4,51.1$ and $37.6 \%$ less than the aluminum residue produced by $\mathrm{Al}-\mathrm{Al}$ electrodes at 15,10 and $5 \mathrm{~V}$ potential, respectively (10 and $5 \mathrm{~V}$ data are not shown). Similarly, iron residue produced by Al-Fe electrodes were 43.9, 48.5 and $63.2 \%$ lower than the iron residue produced by the $\mathrm{Fe}$ Fe electrodes at 15,10 and $5 \mathrm{~V}$ potentials, respectively $(p<0.05)$, which is significantly lower than that of Fe-Fe electrodes (10 and $5 \mathrm{~V}$ data are not shown). Aluminum electrodes (Al-Al) produced significantly higher $\mathrm{Ca}, \mathrm{Cu}$, $\mathrm{K}, \mathrm{Li}, \mathrm{Mg}, \mathrm{Pb}, \mathrm{S}$, Ti and $\mathrm{V}$ residue than the $\mathrm{Al}-\mathrm{Fe}$ and $\mathrm{Fe}-$ Fe electrodes. Similarly, Fe-Fe electrodes produced more $\mathrm{Ag}, \mathrm{As}, \mathrm{Cd}, \mathrm{Ce}, \mathrm{Co}, \mathrm{Mn}, \mathrm{Ni}$ and $\mathrm{Tl}$ residue than the $\mathrm{Al}-\mathrm{Fe}$ and $\mathrm{Al}-\mathrm{Al}$ electrodes.

\section{Comparison of Percentage Reduction of TP, TN and $C O D$ during Electrocoagulation}

For 30 min treatment times, the TP reduction was the highest for all electrode types followed by the COD and $\mathrm{TN}$ reduction for each level of applied voltage potential (Table 2). The TP reduction was about $100 \%$ in all three voltage potentials $(5,10$ and $15 \mathrm{~V})$ within $30 \mathrm{~min}$ of treatment times. Though the percentage reduction of TN and COD increased with the increasing applied voltage potential levels, it did not reach to $100 \%$ under test conditions (30 $\mathrm{min})$.

The higher TP reduction was likely due to the formation of an abundant amount of insoluble metal phosphate when the $\mathrm{OH}$ - released from the cathode react with the soluble phosphate ions already contained in the feedlot runoff during electrocoagulation process according to equations 8-12 (Dinh-Duc et al., 2014; Inan and Alaydin, 2014). Though the reduction of COD was greater than TN, it was lower than TP. The average COD reduction was $>60 \%$ and the main reason of COD reduction was the electrolytic oxidation of organic and inorganic carbon present in the feedlot runoff. The higher percentage of COD reduction than the TN could be due to the presence of simple oxidizable carbon compound in the form of suspended solids and liquids and oxidizing these compounds during the electrocoagulation process (Moreno-Casillas et al., 2007; Yun et al., 2014). TN reduction was lower $(<60 \%)$ and lower TN reduction rate than COD could be due to lower 
denitrification and ammonia stripping process occurred during the electrocoagulation process (Emamjomeh and Sivakumar, 2009; Ilhan et al., 2008; Yun et al., 2014).

Higher electric potential performed better, but it also required higher SEEC (Energy required per unit TP, TN or COD reduction, or per unit volume of feedlot runoff). In general, TN showed the highest SEEC per $\mathrm{kg}$ removed, followed by COD and TP (Table 2). Both Al$\mathrm{Al}$ and $\mathrm{Al}-\mathrm{Fe}$ electrodes performed equally, removed $100 \%$ TP at similar SEEC and outperformed Fe-Fe electrodes. As mentioned before, the lowest SEEC per $\mathrm{kg}$ TP removed was estimated 7.98 for $\mathrm{Al}-\mathrm{Al}$ electrodes. Similarly, the lowest SEEC per kg COD and TN removed were estimated at 4.77 and $70.89 \mathrm{kWh} /$ pollutants for Al-Fe electrode (Table 2). In this research, aluminum based electrodes ( $\mathrm{Al}-\mathrm{Al}$ and $\mathrm{Al}-\mathrm{Fe})$ removed more TP and COD compared to Fe-Fe electrodes. This was likely due to excess active ionization when aluminum ion combined with the hydroxyl ion $(\mathrm{OH}-)$ and contributed to the generation of higher amounts of aluminum hydroxide $\left(\mathrm{Al}(\mathrm{OH})_{3}\right)$ (Hong et al., 2013; Lindsay et al., 1996; Rahman and Borhan, 2014).

Table 2. Comparison of removal efficiencies, Specific Electrical Energy Consumptions (SEEC) at three applied electrical potentials for 30 min electrocoagulation time

\begin{tabular}{|c|c|c|c|c|c|c|c|c|c|c|}
\hline \multirow{2}{*}{$\begin{array}{l}\text { Electrical } \\
\text { potential }\end{array}$} & \multirow{2}{*}{$\begin{array}{l}\text { Current } \\
\text { density } \\
\left(\mathrm{A} / \mathrm{cm}^{2}\right)\end{array}$} & \multicolumn{2}{|c|}{ Percent change } & \multicolumn{3}{|c|}{ Percentage reduction } & \multirow{2}{*}{$\begin{array}{l}\text { Energy } \\
\left(\mathrm{kWh} / \mathrm{m}^{3}\right)\end{array}$} & \multicolumn{3}{|c|}{$\begin{array}{l}\mathrm{SEEC}(\mathrm{KWh} / \mathrm{kg} \\
\text { pollutant removed) }\end{array}$} \\
\hline & & $\mathrm{EC}$ & $\mathrm{pH}$ & TP & COD & $\mathrm{TN}$ & & TP & COD & $\mathrm{TN}$ \\
\hline \multicolumn{11}{|c|}{ Al-Al electrode } \\
\hline $15 \mathrm{~V}$ & 0.036 & 13.28 & $-7.55^{*}$ & 100 & 78.28 & 56.07 & 26.02 & 62.26 & 61.19 & 650.60 \\
\hline $10 \mathrm{~V}$ & 0.020 & 9.72 & $-1.79 *$ & 100 & 73.39 & 46.93 & 9.85 & 29.24 & 24.92 & 321.20 \\
\hline $5 \mathrm{~V}$ & 0.010 & 5.82 & 5.57 & 100 & 66.47 & 45.16 & 2.50 & 7.98 & 8.30 & 89.28 \\
\hline \multicolumn{11}{|c|}{ Fe-Al electrode } \\
\hline $15 \mathrm{~V}$ & 0.023 & 18.97 & $-2.98 *$ & 100 & 78.48 & 62.96 & 16.39 & 26.53 & 39.66 & 482.20 \\
\hline $10 \mathrm{~V}$ & 0.017 & 8.10 & 6.94 & 100 & 67.67 & 42.00 & 8.27 & 20.96 & 23.06 & 295.40 \\
\hline $5 \mathrm{~V}$ & 0.006 & 2.96 & $-0.88^{*}$ & 100 & 58.30 & 38.27 & 1.46 & 10.18 & 4.77 & 70.89 \\
\hline \multicolumn{11}{|c|}{ Fe-Fe electrode } \\
\hline $15 \mathrm{~V}$ & 0.032 & 6.10 & $-22.18 *$ & 100 & 76.75 & 41.44 & 22.99 & 37.65 & 55.28 & 741.80 \\
\hline $10 \mathrm{~V}$ & 0.022 & 5.56 & $-16.02 *$ & 100 & 67.12 & 37.61 & 10.37 & 33.39 & 43.61 & 379.40 \\
\hline $5 \mathrm{~V}$ & 0.010 & 3.57 & $-15.92 *$ & 100 & 53.26 & 27.35 & 2.30 & 20.25 & 23.47 & 118.90 \\
\hline
\end{tabular}

*-sign indicate the increase in value than the initial

Table 3. Concentration of the elements $\left(\mathrm{mgL}^{-1}\right)$ in sludge following the electrocoagulation of runoff wastewater

\begin{tabular}{llll}
\hline Elements & Al-Fe $15 \mathrm{~V}$ & Fe-Fe $15 \mathrm{~V}$ & $\mathrm{Al}-\mathrm{Al} 15 \mathrm{~V}$ \\
\hline $\mathrm{Ag}$ & $1.14 \mathrm{a} * \pm 0.09$ & $2.30 \mathrm{a} \pm 0.12$ & $2.34 \mathrm{a} \pm 0$ \\
$\mathrm{Al}$ & $87313 \mathrm{~b} \pm 6199$ & $822 \mathrm{c} \pm 379$ & $195703 \mathrm{a} \pm 11462$ \\
$\mathrm{As}$ & $64.47 \mathrm{a} \pm 2.57$ & $120.97 \mathrm{a} \pm 2.72$ & $129.87 \mathrm{a} \pm 0$ \\
$\mathrm{~B}$ & $10.53 \mathrm{c} \pm 2.81$ & $17.96 \mathrm{~b} \pm 0.99$ & $23.28 \mathrm{a} \pm 1.45$ \\
$\mathrm{Ba}$ & $14.65 \mathrm{a} \pm 1.77$ & $18.05 \mathrm{a} \pm 2.91$ & $7.13 \mathrm{~b} \pm 2.02$ \\
$\mathrm{Ca}$ & $10597 \mathrm{~b} \pm 1113$ & $13537 \mathrm{a} \pm 832$ & $14698 \mathrm{a} \pm 113$ \\
$\mathrm{Cd}$ & $5.35 \mathrm{~b} \pm 0.31$ & $8.06 \mathrm{a} \pm 1.28$ & $2.69 \mathrm{c} \pm 0.10$ \\
$\mathrm{Ce}$ & $12.09 \mathrm{a} \pm 0.37$ & $23.47 \mathrm{a} \pm 0.85$ & $21.01 \mathrm{a} \pm 0$ \\
$\mathrm{Co}$ & $7.41 \mathrm{~b} \pm 0.03$ & $12.89 \mathrm{a} \pm 0.43$ & $2.14 \mathrm{c} \pm 0.10$ \\
$\mathrm{Cu}$ & $47.02 \mathrm{ab} \pm 11.44$ & $33.98 \mathrm{~b} \pm 8.22$ & $62.49 \mathrm{a} \pm 11.20$ \\
$\mathrm{Fe}$ & $107299 \mathrm{a} \pm 64014$ & $191328 \mathrm{~b} \pm 545$ & $1214 \mathrm{c} \pm 237$ \\
$\mathrm{~K}$ & $4439 \mathrm{~b} \pm 51$ & $4195 \mathrm{~b} \pm 633$ & $6532 \mathrm{a} \pm 368$ \\
$\mathrm{Li}$ & $28.41 \mathrm{a} \pm 8.14$ & $2.85 \mathrm{~b} \pm 0.40$ & $28.59 \mathrm{a} \pm 1.07$ \\
$\mathrm{Mg}$ & $20228 \mathrm{a} \pm 599$ & $11622 \mathrm{~b} \pm 833$ & $20197 \mathrm{a} \pm 656$ \\
$\mathrm{Mn}$ & $327 \mathrm{~b} \pm 13$ & $517 \mathrm{a} \pm 11$ & $149 \mathrm{c} \pm 9$ \\
$\mathrm{Na}$ & $1237 \mathrm{~b} \pm 55$ & $1231 \mathrm{~b} \pm 239$ & $1869 \mathrm{a} \pm 110$ \\
$\mathrm{Ni}$ & $44.13 \mathrm{~b} \pm 1.08$ & $71.92 \mathrm{a} \pm 5.23$ & $13.29 \mathrm{c} \pm 1.35$ \\
$\mathrm{P}$ & $4829 \mathrm{a} \pm 362$ & $3583 \mathrm{~b} \pm 310$ & $3316 \mathrm{~b} \pm 260$ \\
$\mathrm{~Pb}$ & $76.47 \mathrm{~b} \pm 6.56$ & $-22.03 \mathrm{c} \pm 0.36$ & $169.85 \mathrm{a} \pm 9.59$ \\
$\mathrm{~S}$ & $13707 \mathrm{a} \pm 1157$ & $5585 \mathrm{~b} \pm 939$ & $15048 \mathrm{a} \pm 632$ \\
$\mathrm{Si}$ & $72.98 \mathrm{a} \pm 11.10$ & $71.57 \mathrm{a} \pm 24.37$ & $83.84 \mathrm{a} \pm 10.38$ \\
$\mathrm{Sn}$ & $3.27 \mathrm{a} \pm 0.73$ & $3.70 \mathrm{a} \pm 0.22$ & $4.08 \mathrm{a} \pm 0.08$ \\
$\mathrm{Ti}$ & $9.66 \mathrm{a} \pm 2.01$ & $7.52 \mathrm{a} \pm 1.59$ & $11.24 \mathrm{a} \pm 1.43$ \\
$\mathrm{Tl}$ & $6.35 \mathrm{~b} \pm 2.33$ & $10.62 \mathrm{a} \pm 0.83$ & $4.63 \mathrm{~b} \pm 1.27$ \\
$\mathrm{~V}$ & $15.57 \mathrm{~b} \pm 2.02$ & $13.20 \mathrm{~b} \pm 0.73$ & $19.55 \mathrm{a} \pm 1.61$ \\
$\mathrm{Zn}$ & $536.48 \mathrm{a} \pm 564.37$ & $406.15 \mathrm{a} \pm 554.16$ & $329.46 \mathrm{a} \pm 217.09$ \\
\hline
\end{tabular}

*Averages within a row followed by different letters are significantly different at $\mathrm{p}<0.05$ according to Duncan multiple range tests 
Elemental analysis of sludge revealed that except iron residue produced by the $\mathrm{Fe}-\mathrm{Fe}$ electrodes and aluminum residue produced by $\mathrm{Al}-\mathrm{Al}$ electrodes and both residue presented for hybrid electrode, rest of elemental residue presented in sludge was due to the sedimentation of metal residue in a sludge during an electrocoagulation process.

From this batch experiment, it can be concluded that electrocoagulation system may be used with greater implication than other methods such as membrane process or advance oxidation process. For the practical implication, the electrocoagulation process should be used in the continuous mode, which is viable for the livestock's grower because it consumed little amount of electrical energy and requires easily available $\mathrm{Fe}-\mathrm{Fe}$ or $\mathrm{Al}-\mathrm{Al}$ electrodes for the feedlot runoff treatment than the membrane treatment process or other advance wastewater treatment equipment. Also, precipitation of phosphorus from runoff or wastewater stream through the electrocoagulation process may be used as bio-fertilizer. This process, also removed the metal ions due to the sedimentation of soluble metal ion from the feedlot runoff, thus minimizes surface water quality concerns and soil quality concerns. Therefore, this phenomenon clearly indicated electrocoagulation process may be implemented in runoff containing pond or manure storage pond to reduce pollutants from feedlot runoff.

\section{Conclusion}

The comparative performances of three electrodes (Al-Al, Fe-Fe and Al-Fe) in treating feedlot runoff at varying voltage levels and treatment times were evaluated. The following conclusions can be drawn from this experiment:

- Overall, irrespective of electrode types, the percentage $358 \mathrm{TP}$ reduction was the highest, followed by COD and TN

- The reduction efficiencies of nutrients (TP, COD and $\mathrm{TN}$ ) were positively correlated with the increasing treatment times and the applied electrical potential and the energy consumption for each electrode material

- Aluminum electrodes were more effective than the other two electrodes (Al-Fe and $\mathrm{Fe}-\mathrm{Fe}$ ) for reducing high TP $(100 \%)$ and they also consumed lowest specific energy

- Hybrid (Al-Fe) electrodes outperformed Al-Al and $\mathrm{Fe}-\mathrm{Fe}$ electrodes in terms of specific energy consumptions per $\mathrm{kg}$ of COD removed

- Electrocoagulation process demonstrates significant amounts of metal elements in the sludge that indicates the soluble metal ion are settled down from the feedlot runoff after electrocoagulation and it helps to improve wastewater quality after treatment process

- For the practical implication, the electrocoagulation process may be used at the runoff collection pond or settling basin in a continuous mode, since it consumed little electrical energy per $\mathrm{kg}$ of pollutant removed. Also, electrocoagulation process requires low maintenance

\section{Acknowledgement}

Financial support from North Dakota Department of Health and State Board of Agricultural Research and Education (SBARE) are gratefully acknowledged. The authors acknowledge Beef Research Center of North Dakota State University and Mr. Kevin (a cooperating feedlot owner) for providing access to their facilities for collecting runoff.

\section{Author's Contributions}

Arjun Thapa: Former graduate student, who did his M.S.c under Dr. Shafiqur Rahman's supervision. He conducted the experiment, collected and analyzed data. Wrote the manuscript.

Shafiqur Rahman: Supervised the first author. Designed the experiment and helped student in interpreting the data. Reviewed and corrected the manuscript before submitting for publication.

Md Saidul Borhan: Assisted the graduate student in collecting and analyzing data. Reviewed the manuscript.

\section{Ethics}

This manuscript has neither been published, nor under consideration for publication or in press elsewhere concurrently.

\section{References}

Ali, E. and Z. Yaakob, 2012. Electrocoagulation for treatment of industrial effluents and hydrogen production. INTECH Open Sci. Open Minds.

Ansari, A.A., S.S. Gill and F.A. Khan, 2011. Eutrophication: Threat to Aquatic Ecosystems. In: Eutrophication: Causes, Consequences and Control, Ansari, A.A., S.S. Gill, G.R. Lanza and W. Rast (Eds.), Springer, pp: 143-170.

APHA, 2005. Standard Methods for Examination of Water Wastewater. 2nd Edn., American Public Health Association, Washington, D.C.

Basha, C.A., S.J. Selvi, E. Ramasamy and S. Chellammal, 2008. Removal of arsenic and sulphate from the copper smelting industrial effluent. Chem. Eng. J., 141: 89-98.

DOI: $10.1016 /$ j.cej.2007.10.027 
Bazrafshan, E., F.K. Mostafapour, M. Farzadkia, K.A. Ownagh and A.H. Mahvi, 2012. Slaughterhouse wastewater treatment by combined chemical coagulation and electrocoagulation process. Plos One, 7: e40108-e40108. DOI: 10.1371/journal.pone.0040108

Bejan, D., L.M. Rabson and N.J. Bunce, 2007. Electrochemical deodorization and disinfection of hog manure. Canad. J. Chem. Eng., 85: 929-935. DOI: $10.1002 /$ cjce. 5450850615

Bensadok, K., N. El Hanafi and F. Lapicque, 2011. Electrochemical treatment of dairy effluent using combined $\mathrm{Al}$ and $\mathrm{Ti} / \mathrm{Pt}$ electrodes system. Desalination, 280: 244-251.

DOI: $10.1016 /$ j.desal.2011.07.006

Bridle, T. and S. Skrypski-Mantele, 2000. Assessment of sludge reuse options: A life-cycle approach. Water Sci. Technol., 41: 131-135.

Butler, E., Y. Hung, R.Y. Yeh and M.S. Al Ahmad, 2011. Electrocoagulation in wastewater treatment. Water, 3: 495-525. DOI: 10.3390/w3020495

Chaturvedi, S., 2013. Electrocoagulation: A novel wastewater treatment method. Int. J. Modern Eng. Res., 3: 99-100.

Cho, J., J. Lee and C. Ra, 2010. Effects of electric voltage and sodium chloride level on electrolysis of swine wastewater. J. Hazardous Mater., 180: 535-541. DOI: 10.1016/j.jhazmat.2010.04.067

Crane, S.R., J.A. Moore, M.E. Grismer and J.R. Miner, 1983. Bacterial pollution from agricultural sources: A review. Trans. ASABE, 26: 858-866.

DOI: $10.13031 / 2013.34036$

Crites, R.W., E.J. Middlebrooks and R.K. Bastian, 2014. Natural Wastewater Treatment Systems. 2nd Edn., CRC Press, ISBN-10: 1466583266, pp: 549.

Dalvand, A., M. Gholami, A. Joneidi and N.M. Mahmoodi, 2011. Dye removal, energy consumption and operating cost of electrocoagulation of textile wastewater as a clean process. CLEAN-Soil Air Water, 39: 665-672. DOI: $10.1002 /$ clen.201000233

Dillaha, T.A., R.B. Reneau, S. Mostaghimi and D. Lee, 1989. Vegetative filter strips for agricultural nonpoint source pollution control. Trans. Asae, 32: 513-519. DOI: 10.13031/2013.31033

Dinh-Duc, N., S.D. Kim and Y.S. Yoon, 2014. Enhanced phosphorus and COD removals for retrofit of existing sewage treatment by electrocoagulation process with cylindrical aluminum electrodes. Desalinat. Water Treatment, 52: 2388-2399.

DOI: 10.1080/19443994.2013.794707

El-Shazly, A.H., A.A. Al-Zahrani and Y.A. Alhamed, 2013. Kinetics and performance analysis of batch electrocoagulation unit used for the removal of a mixture of phosphate and nitrate ions from industrial effluents. Int. J. Electrochem. Sci., 8: 3176-3185.
Emamjomeh, M.M. and M. Sivakumar, 2009. Denitrification using a monopolar Electrocoagulation/Flotation (ECF) process. J. Environ. Manage., 91: 516-522. DOI: $10.1016 /$ j.jenvman.2009.09.020

Feng, J.W., Y.B. Sun, Z. Zheng, J.b. Zhang and S. Li et al., 2007. Treatment of tannery wastewater by electrocoagulation. J. Environ. Sci., 19: 1409-1415. DOI: 10.1016/S1001-0742(07)60230-7

Gaber, S.E., M.S. Rizk and M.M. Yehia, 2011. Extraction of certain heavy metals from sewage sludge using different types of acids. Biokemistri, 23: 41-48.

Hong, K.H., D. Chang, H.S. Bae, Y. Sunwoo and J.H. Kim et al., 2013. Electrolytic removal of phosphorus in wastewater with noble electrode under the conditions of low current and constant voltage. Int. J. Electrochem. Sci., 8: 8557-8571.

Hribar, C. and M. Schultz, 2010. Understanding concentrated animal feeding operations and their impact on communities. National Association of Local Boards of Health.

Ilhan, F., U. Kurt, O. Apaydin and M.T. Gonullu, 2008. Treatment of leachate by electrocoagulation using aluminum and iron electrodes. J. Hazardous Mater., 154: 381-389. DOI: 10.1016/j.jhazmat.2007.10.035

Inan, H. and E. Alaydin, 2014. Phosphate and nitrogen removal by iron produced in electrocoagulation reactor. Desalinat. Water Treatment, 52: 1396-1403. DOI: $10.1080 / 19443994.2013 .787950$

Inan, H., A. Dimoglo, H. Simsek and A. Karpuzcu, 2004. Olive oil mill wastewater treatment by means of electro-coagulation. Separat. Purificat. Technol., 36: 23-31. DOI: 10.1016/S1383-5866(03)00148-5

Kabuk, H.A., F. Ilhan, Y. Avsar, U. Kurt and O. Apaydin et al., 2014. Investigation of leachate treatment with electrocoagulation and optimization by response surface methodology. CLEAN-Soil Air Water, 42: 571-577. DOI: 10.1002/clen.201300086

Kılıç, M.G. and Ç. Hoşten, 2010. A comparative study of electrocoagulation and coagulation of aqueous suspensions of kaolinite powders. J. Hazardous Mater., 176: 735-740. DOI: 10.1016/j.jhazmat.2009.11.097

Kim, D., W. Kim, C. Yun, D. Son and D. Chang et al., 2013. Agro-industrial wastewater treatment by electrolysis technology. Int. J. Electrochem. Sci., 8: 9835-9850.

Laridi, R., P. Drogui, H. Benmoussa, J.F. Blais and J.C. Auclair, 2005. Removal of refractory organic compounds in liquid swine manure obtained from a biofiltration process using an electrochemical treatment. J. Environ. Eng., 131: 1302-1310. DOI: 10.1061/(ASCE)0733-9372(2005)131:9(1302)

Lindsay, W., P. Walthall and G. Sposito, 1996. The environmental chemistry of aluminum. 
Lucas, M.S. and J.A. Peres, 2009. Removal of COD from olive mill wastewater by Fenton's reagent: Kinetic study. J. Hazardous Mater., 168: 1253-1259. DOI: 10.1016/j.jhazmat.2009.03.002

Merzouk, B., B. Gourich, K. Madani, C. Vial and A. Sekki, 2011. Removal of a disperse red dye from synthetic wastewater by chemical coagulation and continuous electrocoagulation. A comparative study. Desalination, 272: 246-253.

DOI: 10.1016/j.desal.2011.01.029

Merzouk, B., B. Gourich, A. Sekki, K. Madani and C. Vial et al., 2009. Studies on the decolorization of textile dye wastewater by continuous electrocoagulation process. Chem. Eng. J., 149: 207-214. DOI: 10.1016/j.cej.2008.10.018

Mollah, M.Y.A., R. Schennach, J.R. Parga and D.L. Cocke, 2001. Electrocoagulation (EC)-science and applications. J. Hazardous Mater., 84: 29-41. DOI: 10.1016/S0304-3894(01)00176-5

Moreno-Casillas, H.A., D.L. Cocke, J.A.G. Gomes, P. Morkovsky and J.R. Parga et al., 2007. Electrocoagulation mechanism for COD removal. Separat. Purificat. Technol., 56: 204-211. DOI: 10.1016/j.seppur.2007.01.031

Prophet, C.W. and N.L. Edwards, 1973. Benthic macroinvertebrate community structure in a great plains stream receiving feedlot runoff. J. Am. Water Resources Assoc., 9: 583-589. DOI: 10.1111/j.1752-1688.1973.tb01772.x

Rahman, S. and M.S. Borhan, 2014. Electrolysis of swine manure effluents using three different electrodes Fe-Fe, Al-Al and Fe-Al. Am. J. Agric. Biol. Sci., 9: 490-502.

DOI: 10.3844/ajabssp.2014.490.502

Rivera, M., M. Pazos and M. Sanroman, 2009. Improvement of dye electrochemical treatment by combination with ultrasound technique. J. Chem. Technol. Biotechnol., 84: 1118-1124.

DOI: $10.1002 /$ jctb. 2141

Rodriguez, J., S. Stopic, G. Krause and B. Friedrich, 2007. Feasibility assessment of electrocoagulation towards a new sustainable wastewater treatment. Environ. Sci. Pollut. Res., 14: 477-482. DOI: 10.1065/espr2007.05.424

Sangal, V.K., I.M. Mishra and J.P. Kushwaha, 2013. Electrocoagulation of soluble oil wastewater: Parametric and kinetic study. Separat. Sci. Technol., 48: 1062-1072.

DOI: $10.1080 / 01496395.2012 .719985$

Sano, A., M. Kanomata, H. Inoue, N. Sugiura and K.Q. $\mathrm{Xu}$ et al., 2012. Extraction of raw sewage sludge containing iron phosphate for phosphorus recovery. Chemosphere, 89: 1243-1247.

DOI: 10.1016/j.chemosphere.2012.07.043
Şengil, İ.A., 2006. Treatment of dairy wastewaters by electrocoagulation using mild steel electrodes. J. Hazardous Mater., 137: 1197-1205.

DOI: 10.1016/j.jhazmat.2006.04.009

Sethu, V.S., A.R. Aziz and M.K. Aroua, 2008. Recovery and reutilisation of copper from metal hydroxide sludges. Clean Technol. Environ. Policy, 10: 131-136. DOI: $10.1007 / \mathrm{s} 10098-007-0133-4$

Spellman, F.R. and N.E. Whiting, 2010. Environmental Management of Concentrated Animal Feeding Operations (CAFOs). 1st Edn., CRC Press.

Tchamango, S., C.P. Nanseu-Njiki, E. Ngameni, D. Hadjiev and A. Darchen, 2010. Treatment of dairy effluents by electrocoagulation using aluminium electrodes. Sci. Total Environ., 408: 947-952. DOI: 10.1016/j.scitotenv.2009.10.026

Yavuz, Y., E. Ocal, A.S. Koparal and U.B. Ogutveren, 2011. Treatment of dairy industry wastewater by EC and EF processes using hybrid Fe-Al plate electrodes. J. Chem. Technol. Biotechnol., 86: 964-969. DOI: $10.1002 /$ jctb.2607

Yi-Zhong, J., Z. Yue-Feng and L. Wei, 2002. Experimental study on micro-electrolysis technology for pharmaceutical wastewater treatment. J. Zhej. Univ. Sci., 3: 401-404. DOI: $10.1631 /$ jzus.2002.0401

Yun, C., D. Kim, W. Kim, D. Son and D. Chang et al., 2014. Application and assessment of enhanced electrolytic process for laundry wastewater treatment. Int. J. Electrochem. Sci., 9: 1522-1536.

\section{Supplementary Information}

\section{Electrocoagulation Mechanism}

Anode generates the coagulant in situ by electrolytic oxidation during electrocoagulation. Charged ionic species are removed from wastewater by allowing it to react with either (i) ions having opposite charge, or (ii) flocs of metallic hydroxides generated within the effluent (Mollah et al., 2001). Electro-flotation, electro-oxidation and electrocoagulation occur simultaneously and particles aggregate by following at least one or a combination of any of the above-mentioned mechanisms. Flocculation can enhance by continuous mixing. In this study, three different types of electrodes were used. Some of the reaction mechanisms that take place in the anode and cathode were presented below (El-Shazly et al., 2013; Lucas and Peres, 2009; Sangal et al., 2013).

At the Aluminum (Al-Al) electrode:

$A l(s) \rightarrow A l^{3+}(a q)+3 e^{-}($at anode $)$ 


$$
\begin{aligned}
& 3 \mathrm{H}_{2} \mathrm{O}(\mathrm{l})+3 e^{-} \rightarrow 3 / 2 \mathrm{H}_{2}(\mathrm{~g})+3 \mathrm{OH}^{-}(\text {at cathode }) \\
& \mathrm{Al}^{3+}(\mathrm{aq})+3 \mathrm{OH}^{-}(\mathrm{aq}) \rightarrow \mathrm{Al}(\mathrm{OH})_{3}(s)(\text { overall reaction })
\end{aligned}
$$

The aluminum hydroxide flocs have large surface area, are adsorbed, trapped or polymerized colloidal particles and can be removed from the aqueous solution. Aluminum hydroxide is also an important adsorbent of organic and inorganic ions, molecules and colloidal particles (Rodriguez et al., 2007). At the Fe-Fe electrode:

$$
\begin{aligned}
& \mathrm{Fe}(s) \rightarrow \mathrm{Fe}^{2+}(a q)+2 e^{-}(\text {at anode }) \\
& 2 \mathrm{H}_{2} \mathrm{O}(1)+2 e-\rightarrow \mathrm{H}_{2}(\mathrm{~g})+2 \mathrm{OH}^{-}(\text {aq })(\text { at cathode }) \\
& \mathrm{Fe}(s)+2 \mathrm{H}_{2} \mathrm{O}(1) \rightarrow \mathrm{Fe}(\mathrm{OH})_{2}(\mathrm{~S}) \\
& +\mathrm{H}_{2}(\mathrm{~g})(\text { overall reaction }) \text { and / or } \\
& 4 \mathrm{Fe}(\mathrm{s})+10 \mathrm{H}_{2} \mathrm{O}(1)+\mathrm{O}_{2}(\mathrm{~g}) \rightarrow 4 \mathrm{Fe}(\mathrm{OH})_{3}(s) \\
& +4 \mathrm{H}_{2}(\mathrm{~g})(\text { overall reaction })
\end{aligned}
$$

The liberated $\mathrm{Fe}^{2+}$ and $\mathrm{OH}^{-}$react with various monomeric or polymeric iron hydrolyzed species and adsorb pollutants present in the wastewater to form bigger size flocs that settled down.

\section{Pollutant Reduction Mechanism Due to E Electrocoagulation Process}

\section{Total Phosphorus (TP) Reduction Mechanism}

During electrocoagulation, $\mathrm{OH}^{-}$liberated from the cathode reacts with soluble phosphatecontaining material and liberate $\mathrm{PO}_{4}{ }^{3-}$. The $\mathrm{PO}_{4}{ }^{3-}$ reacts with the metal ions and produced metal phosphates such as $\mathrm{AlPO}_{4}$ or $\mathrm{FePO}_{4}$ by covalent bonds. The $\mathrm{AlPO}_{4}$ or $\mathrm{FePO}_{4}$ are insoluble in water and settle to the bottom. During the process of settlement, these ions thereafter the micro colloidal particles absorb micro-colloidal particles. Thus, the absorbed micro-colloidal particles form flocs, which is settling down to the bottom and decreasing the amount of TP from the effluent or runoff:

$$
\begin{aligned}
& \mathrm{Al}(\mathrm{s}) \rightarrow \mathrm{Al}^{3+}(a q)+3 e^{-}(\text {at anode }) \\
& 3 \mathrm{H}_{2} \mathrm{O}(1)+3 e^{-} \rightarrow 3 / 2 \mathrm{H}_{2}(g)+3 \mathrm{OH}^{-}(a q)(\text { at cathode }) \\
& \mathrm{H}_{3} \mathrm{PO}_{4}(a q)+3 \mathrm{OH}^{-}(a q) \rightarrow 3 \mathrm{H}_{2} \mathrm{O}(1)+\mathrm{PO}_{4}{ }^{3-}(a q) \\
& \mathrm{Al}^{3+}(a q)+\mathrm{PO}_{4}{ }^{3+}(a q) \rightarrow \mathrm{AlPO}_{4}(s)
\end{aligned}
$$

$$
\begin{aligned}
& \mathrm{Al}(\mathrm{s})+\mathrm{H}_{3} \mathrm{PO}_{4}(\mathrm{aq}) \rightarrow \mathrm{AlPO}_{4}(s) \\
& +3 / 2 \mathrm{H}_{2}(\mathrm{~g})(\text { Overall reaction })
\end{aligned}
$$

\section{Total Nitrogen (TN) Reduction Mechanism}

According to the EPA, TN is the sum of organic nitrogen, $\mathrm{NH}_{4}-\mathrm{N}$ and $\mathrm{NO}_{2}-\mathrm{N}+\mathrm{NO}_{3}-\mathrm{N}$. Therefore, a TN reduction during electrocoagulation is the reduction of organic nitrogen, $\mathrm{NH}_{4}-\mathrm{N}$ and $\mathrm{NO}_{2}-\mathrm{N}+\mathrm{NO}_{3}-\mathrm{N}$. The $\mathrm{NO}_{2}$ $\mathrm{N}+\mathrm{NO}_{3}-\mathrm{N}$ present in the runoff is reduced by a chemical denitrification process with the help of metal electrodes such as aluminum or iron during the electrocoagulation process. The overall denitrification process during an electrocoagulation process is given below (Emamjomeh and Sivakumar, 2009):

$$
\begin{aligned}
& 3 \mathrm{NO}_{3}{ }^{-}(a q)+6 \mathrm{Al}(s)+12 \mathrm{H}_{2} \mathrm{O}(1) \rightarrow 3 \mathrm{NH}_{3}(g) \\
& +\mathrm{N}_{2}(g)+6 \mathrm{Al}(\mathrm{OH})_{3}(s)+3 \mathrm{OH}^{-}(a q) \\
& 3 \mathrm{NO}_{3}{ }^{-}(a q)+6 \mathrm{Fe}(s)+12 \mathrm{H}_{2} \mathrm{O}(1) \rightarrow 3 \mathrm{NH}_{3}(g) \\
& +\mathrm{N}_{2}(\mathrm{~g})+6 \mathrm{Fe}(\mathrm{OH})_{3}(s)+3 \mathrm{OH}^{-}(a q)
\end{aligned}
$$

The $\mathrm{NO}_{2}-\mathrm{N}+\mathrm{NO}_{3}-\mathrm{N}$ present in the runoff or wastewater is removed in the form of nitrogen and ammonia from the wastewater during electrocoagulation by denitrification (Equation 13 and 14). Similarly, hydrogen electro-flotation process occurs at the cathode and $\mathrm{NH}_{4}-\mathrm{N}$ present in the wastewater or runoff removes by an ammonia stripping method. Ammonia is also removed by electro-oxidation at the anode (Kabuk et al., 2014). The ammonia striping method is enhanced by high $\mathrm{pH}(>8)$, high temperature $\left(>50^{\circ} \mathrm{C}\right)$ and, high airflow rate (Emamjomeh and Sivakumar, 2009; Ilhan et al., 2008). The overall reaction during the ammonia stripping method is as equation 15 . According to Yun et al. (2014) the organic nitrogen present in the solution is also removed during the electrocoagulation process is as Equation 16 to 18 . Therefore, in electrocoagulation, a different process reduces all types of nitrogen and its effect is reflected significantly in $\mathrm{TN}$ reduction:

$$
\begin{aligned}
& \mathrm{NH}_{4}^{+}(a q)+\mathrm{OH}^{-}(a q) \rightarrow \mathrm{NH}_{3}(g)+\mathrm{H}_{2} \mathrm{O}(1) \\
& \mathrm{H}_{2} \mathrm{O}(1) \rightarrow \mathrm{H}^{+}(a q)+\mathrm{OH}^{-}(a q) \\
& \operatorname{Metal}(s)+n \mathrm{OH}^{-}(a q) \\
& + \text { Organics }(a q)+\mathrm{O}_{2}(g) \\
& \rightarrow \text { Oxidized Organics }-\operatorname{Metal}(\mathrm{OH}) n \downarrow(s)+n e^{-} \\
& \mathrm{H}^{+}(a q)+e^{-} \rightarrow \mathrm{H}_{2}
\end{aligned}
$$




\section{Chemical Oxygen Demand (COD) Reduction Mechanism}

Chemical Oxygen Demand (COD) is the amount of the oxygen needed for the chemical oxidation of inorganic and organic matter present in wastewater. Compounds that contribute to COD are biodegradable organic compounds, non-biodegradable compounds and inorganic oxidizable compounds (Moreno-Casillas et al., 2007). According to Yun et al. (2014), the reduction of organic compounds occurred by the electrolytic oxidation and electrocoagulation process. During electrolytic oxidation, organic compounds convert into carbon dioxide gas by complete oxidation processes (Equation 21):

$$
\begin{aligned}
& 2 \mathrm{H}_{2} \mathrm{O}(1) \rightarrow 4 \mathrm{H}^{+}(a q)+\mathrm{O}_{2}(g)+4 e^{-} \\
& \mathrm{OH}^{-}(a q) \rightarrow 2 \mathrm{H}_{2} \mathrm{O}(1)+\mathrm{O}_{2}(g)+4 e^{-}
\end{aligned}
$$

$\operatorname{Organics}(a q)+\mathrm{O}_{2}(g) \rightarrow \mathrm{H}_{2} \mathrm{O}(1)+\mathrm{CO}_{2}(g)$

Organic or inorganic compounds present in feedlot runoff react with the metal hydroxide and produce an insoluble compound (Equation 16 to 18). The COD reduction is also promoted by the upward flow of hydrogen gas produced during the electrocoagulation process at the cathode. The soluble COD compound formed during electrocoagulation does not help with COD reduction (Ali and Yaakob, 2012; Moreno-Casillas et al., 2007). 